\title{
Spindle Cell Lipoma: A Case Report And Review Of Literature
}

\author{
Chandrashekar $\mathrm{P},{ }^{1}$ Jose $\mathrm{M},{ }^{1}$ Dadhich $\mathrm{M},{ }^{1}$ Chatra $\mathrm{L},{ }^{2}$ Holla $\mathrm{V}^{2}$
}

${ }^{1}$ Department of Oral \& Maxillofacial Pathology

${ }^{2}$ Department of Oral Medicine and Radiology

Yenepoya Dental College, Yenepoya University

Deralakatte, Mangalore

\begin{abstract}
Oral spindle cell lipoma is a rare lesion and until now only 26 cases have been reported in English literature. In this article we report a case of oral spindle cell lipoma presented to our institution in July 2011, as an asymptomatic solitary growth of the buccal mucosa in a 58 year old male patient. On histopathological examination the lesion exhibited an admixture of adipocytes and spindle cells with collagen fibres and numerous mast cells.
\end{abstract}

Corresponding Author

Pavitra Chandrashekar

Department of Oral \& Maxillofacial Pathology

Yenepoya Dental College, Yenepoya University

Deralakatte, Mangalore

\section{KEYWORDS}

Lipoma, Spindle cells, Spindle cell lipoma

E-mail: drpavitra.c@gmail.com

Citation

Chandrashekar P, Jose M, Dadhich M, Chatra L, Holla V. Spindle Cell Lipoma: A Case Report And Review Of Literature. Kathmandu Univ Med J 2012;38(2):92-95.

\section{INTRODUCTION}

Lipoma is a common tumor of adipose tissue, present in the oral and oropharyngeal region. The overall incidence in the oral cavity is $1-4.4 \%$ of all benign oral lesions. ${ }^{1}$ Oral lipoma can occur in various anatomic sites including buccal mucosa, lip, tongue, palate, vestibule and the floor of the mouth. The common variants of lipoma are simple lipomas and fibrolipomas, and rarer variants include angiolipoma, intramuscular lipoma, pleomorphic lipoma and spindle cell lipoma. ${ }^{2}$

The spindle cell lipomas (SCL) are infrequent histological variant of lipoma, first described by Enzinger and Harvey in 1975. This mainly present as well circumscribed subcutaneous lesion of mature adipose tissue. ${ }^{3}$ They are most commonly known to occur in posterior neck, upper back and shoulders. There have been few reports of spindle cell lipoma occurring in thigh, groin, buttock, face, hands and the oral cavity. Spindle cell lipomas are usually seen in elderly males in fifth to seventh decade. ${ }^{4}$

\section{CASE REPORT}

A 58 year old man reported to Department of Oral Diagnosis, Yenepoya Dental College, Yenepoya University, Mangalore, India on 13th July 2011 for consultation regarding a swelling in the right buccal mucosa. The lesion had appeared two to three years back, slowly grown without any accompanying symptoms, to reach the present size. On oral examination a well-defined solitary growth was observed on right buccal mucosa. The growth was about $1 \times 1 \mathrm{~cm}$ in size, pedunculated, non-tender, nonfluctuant and rubbery in consistency. The color was similar to the adjacent mucosa and surface appeared smooth and glossy. A provisional diagnosis of fibroma was given (Fig1). The lesion was excised under local anesthesia and submitted for histopathological examination.

On gross examination, the specimen received by the department of oral pathology was $1 \times 1 \mathrm{~cm}$ size having a smooth surface and rubbery consistency (Fig 2). On microscopic examination the sections exhibited an admixture of mature adipocytes and spindle cells. The mature lipocytes were arranged in lobules separated by connective tissue septa (Fig 3). The connective tissue septae 

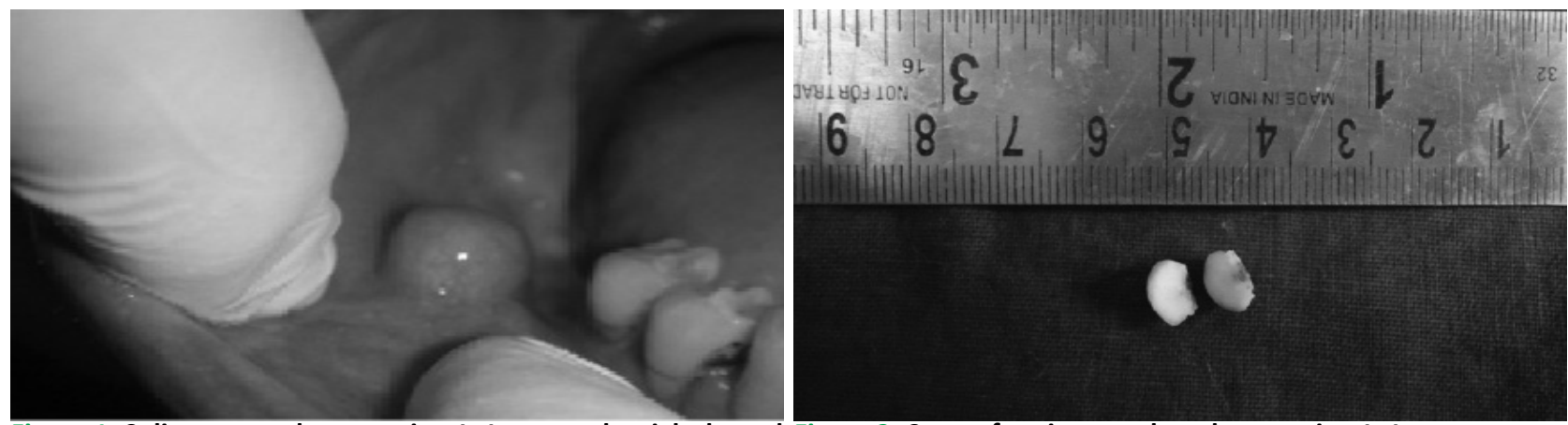

Figure 1 . Solitary growth measuring $1 \times 1 \mathrm{cms}$ on the right buccal Figure 2 . Cut surface is smooth and measuring $1 \times 1 \mathrm{~cm}$.
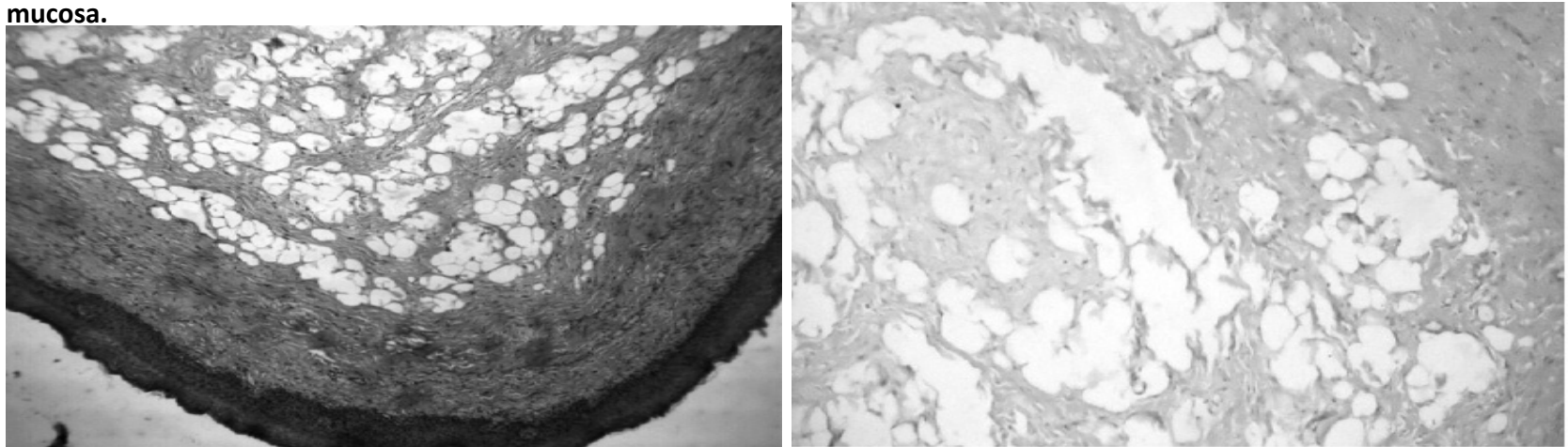

Figure 3. Photomicrograph showing collection of fat cells Figure 4.Admixture of fat cells and Spindle Cells with bundles of separated by connective tissue septa (4x, H\&E stain). collagen fibers (photomicrograph 10XH\&E Stain).

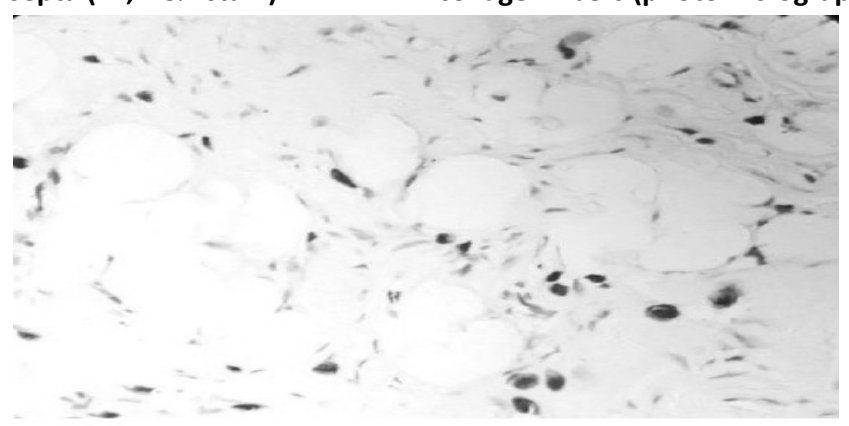

Figure 5. Photomicrograph exhibiting numerous metachromatic Mast cells (40 X, Toluidine Blue Stain).

were composed of bundles of collagen fibers and fibroblast like spindle cells (Fig 4). The spindle cells contained bland uniform nuclei and pale eosinophilic cytoplasm and were arranged in short fascicles in some areas. No mitosis was observed. The sections also showed scanty areas of myxoid degeneration and numerous Mast cells, found to be distributed throughout the stroma. Toluidine Blue staining which is a special stain for mast cell was performed to confirm the presence of these cells. (Fig 5)

\section{DISCUSSION}

Lipomas are relatively common benign soft tissue neoplasm affecting the oral cavity. The first description of lipoma in the oral cavity was given by Roux in 1848; he referred to it as a yellow epulis. ${ }^{5}$ Oral lipomas are generally slow enlarging, soft smooth surfaced mass of the submocosal tissues. ${ }^{7}$ Some of the theories put forward to explain the pathogenesis are heredity, fatty degeneration, hormonal basis, trauma, infection, infarction, metaphase of muscle cells, lipoblastic embryonic cell nest in origin and chronic irritation. ${ }^{7}$ Few reports suggest that oral lipomas occur due to chromosomal aberrations such as translocations involving 12q13-15, locus interstitial deletions of 13q, and rearrangements involving $8 q 11-13$ locus. ${ }^{8}$ Karyotypic abnormalities specific to spindle cell lipoma are restricted to13q and 16q.

We conducted a literature search of medline and google databases from 1984 ever since the term spindle cell lipoma was described first. The search was conducted using the terms- Lipoma, Spindle cells, Spindle cell lipoma to retrieve all the cases reported in English literature. After extensive search, we could got details of 26 cases of spindle cell lipomas in the oral cavity reported in the past(table I). Of the included 26 cases reported, 16 SCLs have been reported in males and $10 \mathrm{SCLs}$ in females. The average age range is 29 to $71 \mathrm{yrs}$. The specific anatomic locations are floor of mouth $(\mathrm{N}=4)$, tongue $(\mathrm{N}=10)$, Cheek $(\mathrm{N}=8)$, gingiva $(N=1)$, alveolar ridge $(N=1)$, hard palate $(N=1)$, buccal mucosa $(\mathrm{N}=1)$.

Enzinger and Harvery described SCLs as round circumscribed lesions which may sometimes infiltrate into the surrounding 
Table 1. Clinical detail of all reported cases of intra-oral spindle cell lipoma.

\begin{tabular}{|c|c|c|c|c|c|}
\hline Case No & Authors & Year & Age & Gender & $\begin{array}{l}\text { Location of } \\
S C L\end{array}$ \\
\hline 1 & $\begin{array}{l}\text { Mc Daniel } \\
\text { et al }\end{array}$ & 1984 & 33 & $\mathrm{~F}$ & $\begin{array}{l}\text { Floor of } \\
\text { Mouth }\end{array}$ \\
\hline 2 & $\begin{array}{l}\text { Mc Daniel } \\
\text { et al }\end{array}$ & 1984 & 52 & $M$ & Tongue \\
\hline 3 & $\begin{array}{l}\text { Christopou- } \\
\text { lous et al }\end{array}$ & 1989 & 58 & $M$ & Hard palate \\
\hline 4 & Levy et al. & 1989 & 74 & $\mathrm{~F}$ & $\begin{array}{l}\text { Floor of } \\
\text { Mouth }\end{array}$ \\
\hline 5 & $\begin{array}{l}\text { Lombardi } \\
\text { and Odell }\end{array}$ & 1994 & 68 & $\mathrm{~F}$ & Tongue \\
\hline 6 & Tosios et al. & 1995 & 55 & $M$ & Cheek \\
\hline 7 & Khoo et al. & 1995 & 23 & $M$ & Cheek \\
\hline 8 & $\begin{array}{l}\text { Yamagata } \\
\text { et al. }\end{array}$ & 1999 & 45 & $\mathrm{~F}$ & Cheek \\
\hline 9 & $\begin{array}{l}\text { Piattelli } \\
\text { et al. }\end{array}$ & 1999 & 75 & $M$ & Cheek \\
\hline 10 & Dutt et al. & 1999 & 42 & $\mathrm{~F}$ & Tongue \\
\hline 11 & Donen et al. & 2000 & 71 & $M$ & Tongue \\
\hline 12 & $\begin{array}{l}\text { Piattelli } \\
\text { et al. }\end{array}$ & 2000 & 63 & $M$ & Cheek \\
\hline 13 & Agoff et al. & 2001 & 61 & $\mathrm{~F}$ & Gingiva \\
\hline 14 & $\begin{array}{l}\text { Said-Al- } \\
\text { Naief et al. }\end{array}$ & 2001 & 66 & $M$ & Tongue \\
\hline 15 & $\begin{array}{l}\text { Said-Al- } \\
\text { Naief et al. }\end{array}$ & 2001 & 53 & $\mathrm{~F}$ & Tongue \\
\hline 16 & $\begin{array}{l}\text { Darling et } \\
\text { al. }\end{array}$ & 2002 & 69 & $M$ & Alveolar ridge \\
\hline 17 & Asoda et al. & 2003 & 56 & $M$ & Tongue \\
\hline 18 & Nagisa et al. & 2003 & 64 & $M$ & Cheek \\
\hline 19 & $\begin{array}{l}\text { Yamada } \\
\text { et al. }\end{array}$ & 2003 & 44 & $\mathrm{~F}$ & Cheek \\
\hline 20 & Kaku et al. & 2003 & 75 & $M$ & $\begin{array}{l}\text { Tongue (Mul- } \\
\text { tiple }\end{array}$ \\
\hline 21 & Piatteli et al. & 2005 & 50 & $M$ & Floor of mouth \\
\hline 22 & $\begin{array}{l}\text { Matsuura } \\
\text { et al. }\end{array}$ & 2005 & 75 & $M$ & Tongue \\
\hline 23 & $\begin{array}{l}\text { Kawasaki } \\
\text { et al. }\end{array}$ & 2006 & 42 & $\mathrm{~F}$ & Cheek \\
\hline 24 & $\begin{array}{l}\text { Filipe Coim- } \\
\text { bra et al. }\end{array}$ & 2006 & 29 & $\mathrm{~F}$ & Floor of mouth \\
\hline 25 & $\begin{array}{l}\text { Tomaski } \\
\text { et al. }\end{array}$ & 2008 & 72 & $M$ & $\begin{array}{l}\text { Tongue (Mul- } \\
\text { tiple) }\end{array}$ \\
\hline 26 & $\begin{array}{l}\text { Vecchio, } \\
\text { Giada et al. }\end{array}$ & 2009 & 54 & $M$ & Buccal mucosa \\
\hline 27 & $\begin{array}{l}\text { Present } \\
\text { Case. }\end{array}$ & 2011 & 58 & $M$ & Buccal mucosa \\
\hline
\end{tabular}

tissue. Grossly the lesions are tan to yellowish white in color with an average size of 4 to $5 \mathrm{~cm}$. Microscopically SCLs are composed of mature adipocytes with widely scattered to numerous spindle cells, thick bundles of collagen, and mast cells. Myxoid degeneration of the stroma is reported in most of the case reports. Mitoses and cellular pleomorphism is very rare. The spindle cells comprise of a pale staining vesicular, oval or compressed nuclei, and the cytoplasm is scant poorly defined and esinophilic. ${ }^{11-13}$ The spindle cells are uniformly shaped, arranged in parallel fashion, having a single elongated and narrow nucleus, bipolar cytoplasmic processes with features similar to fibroblasts ${ }^{3}$ The spindle cells are thought to be of fibroblastic in origin or similar to the non-lipoblastic stellate mesenchymal cells of the primitive fat lobules which have the ability to synthesis collagen. ${ }^{11}$ Some researchers have suggested that the spindle cells represent an immature cell of mesenchymal nature arrested at an early stage in its development to a mature lipocyte. ${ }^{14-17}$ Electron microscopic study conducted by Henryk. A et al showed that some of the spindle cells have some features of fibroblasts while some contained nonmembrane bound lipid droplets, suggesting a prelipoblastic nature. ${ }^{10}$ Mast cells have been observed in all the reported cases of SCLs. The significance of the mast cells in this tumor is not known.

The histopathologic differential diagnosis include simple lipoma, Pleomorphic lipoma and tumors of nerve tissue origin. SCLs can be differentiated from Simple lipoma as the latter lesions do not exhibit extensive collagen bundles with spindle cells and mast cells. ${ }^{18}$ Presence of multinucleated floret-like giant cells with multiple radially arranged nuclei is more characteristic of pleomorphic lipoma. Fibrolipoma histologically is diagnosed based on the presence of mature adipose tissue interspersed by bands of broad or fascicles of dense connective tissue fibers with the capsule. ${ }^{19}$ Myxolipoma consists of adipose tissue without lipoblasts, extensive myxoid areas, and numerous blood vessels..$^{20,21}$

SCLs must be differentiated from nerve tumors like schwannoma and neurofibroma. Diagnostic difficulty may arise when these tumors infiltrate the surrounding adipose tissue. Distinct histopathological features with positive immunostaining of spindle cells with S100 protein would help in identifying nerve tumors. ${ }^{21}$

Careful identification of this benign lesion is necessary to avoid misdiagnosing it as its malignant counterparts including Spindle cell WD Liposarcoma, fibrosarcoma, Myxoidliposarcoma etc. ${ }^{18,21}$ Spindle Cell Well Differentiated Liposarcoma have atypical lipogenic cells showing variations in size and shape, and spindled tumor cells with slightly enlarged, often hyperchromatic nuclei with mild atypia. Spindle cells may be arranged in short fascicles, whorls or in storiform fashion, admixed with a well-differentiated liposarcomatous component and focal myxoid stromal changes. Bland cellular features and clinical presentation would help in differentiating both. SCL with marked myxoid changes sometimes may be confused with myxoidliposarcoma as well as low-grade myxofibrosarcoma (MFS). Myxoidliposarcoma is usually deep-seated and shows delicate, branching blood vessels that, together with lipoblasts, help to make a correct diagnosis. Immunocytochemical studies with CD-34, bcl-2,21,24 can be helpful in the differentiation of SCL from MFS and other myxoid lesions. ${ }^{18,20,21}$ The treatment of spindle cell lipoma involves surgical excision with virtually no recurrences. 


\section{CONCLUSION}

The oral spindle cell lipoma is a benign soft tissue tumor with distinctive histopathologic features. Although there is no prognostic significance in identifying this lesion as a separate entity, a clear understanding about this would help the pathologist to give a definite diagnosis and differentiate it from malignant counterparts.

\section{REFERENCES}

1. Sridhar Reddy P, Ananth Naag, Bina Kashyap. Case Report: Intramuscular (infiltrating) Lipoma. Online Journal of Health and Allied Sciences. 2010; 9(4):23.

2. Eduardo-Costa Studart-Soares, Fábio-Wildson-Gurgel Costa, FabrícioBitu Sousa , Ana-Paula-Negreiros- NunesAlves, Rafael-Lima-Verde Osterne . Oral lipomas in a Brazilian population: A 10-year study and analysis of 450 cases reported in the literature Eduardo. Med Oral Patol Oral Cir Bucal. 2010;15: e691-6.

3. Enzinger FM, Harvey DA: Spindle Cell Lipoma. Cancer. 1975;36:18521859.

4. Naomi Kaku, Kenji Kashima, Tsutomu Daa, Iwao Nakayama, Hideomi Kerakawauchi. Multiple spindle cell lipomas of the tongue: report of a case. APMIS. 2003; 111(5):581-585.

5. Rajendran R, Sivapathasundharam B. Shafer's textbook of oral pathology. 6th Edition. India: Elsevier, 2009.

6. Suga.H, Eto.H, Inoue.K, Aoi.N, Kato.H: Cellular and molecular features of lipoma tissue comparison with normal adipose tissue. British Journal of Dermatology. 2009; 161:819-825

7. Furlong MA, Fanburg-Smith JC, Childers EL. Lipoma of the oral and maxillofacial region: Site and subclassification of 125 cases. Oral Surg Oral Med Oral Pathol Oral Radiol Endod. 2004; 98:441-450.

8. Giuseppe Colella, Paolo Biondi, Rosario Caltabiano, Giada Maria Vecchio, Paolo Amico. Giant intramuscular lipoma of the tongue: a case report and literature review. Cases J. 2009; 2: 7906.

9. Adriano Piattelli, Massimiliano Fioroni, Corrado Rubini: Spindle cell Lipoma of the oral Cavity: Report of a Case. J oral MaxillofacSurg.1999; 57: 624-625.

10. Henryk A. Domanski, Birgitta Carle' $n$, Kjell Jonsson, Fredrik Mertens, Måns Åkerman. Distinct Cytologic Features of Spindle Cell Lipoma A Cytologic-Histologic Study with Clinical, Radiologic, Electron Microscopic, and Cytogenetic Correlations. Cancer. 2001;93(6):381389.

11. Alfred Beham, Christine Schmid, Stefan Hödl, Christopher D. M. Fletcher. Spindle cell and pleomorphic lipoma: An immunohistochemical study and histogenetic analysis. The Journal of Pathology. 1989; 158(3): 219-222.
12. Nil Comunoglu, Cem Comunoglu, A. Isin Dogna Ekic, Ferda Ozkan, Sergulen Dervisoglu. Spindle Cell Lipoma. Pol J Pathol. 2007;58 (1):711.

13. McDaniel R. K, Newland J. R and Chiles D. G. Intraoral spindle cell lipoma: Case report with correlated light and electron microscopy. Oral Surgery, Oral Medicine, Oral Pathology.1984;57(1):52-55.

14. Filipe Coimbra, Lopes J.M, Helena Figuriral. Crispian Scully: Spindle cell lipoma of the floor of the mouth. A Case Report. Med Oral Patol Oral Cir Bucal. 2006; 11: 401-3.

15. Goro Kawasaki, Souichi Yanamto, Kazunari Hirata, Akio Mizuno, Shuichi Fujita, Tohru Ikeda. Spindle cell lipoma of the cheek: A case report and review of literature Oral Oncology. EXTRA. 2006 ;42: 301304.

16. Matsuura Keiko Akizuki, Shinichiro Hirano, Kimihiko Yanagisawa, Shigetaka Moriyama, Masatsugu. A case of spindle cell lipoma arising in the tongue. Oral Oncology 2005;41(10):292-295.

17. Sekar B, Dominic Augustine, Murali S. Lipoma, a rare intraoral tumora case report with review of literature. Journal of Oral \& Maxillofacial Pathology. 2011;2(2):174-177.

18. Douglas Gneep R (2001) Diagnostic Surgical Pathology of the Head \& Neck, W.B.Saunders Company, (1 sted), 192-192.

19. Mentzel T, Palmedo G, Kuhnen C. Well-differentiated spindle cell liposarcoma ('atypical spindle cell lipomatous tumor') does not belong to the spectrum of atypical lipomatous tumor but has a close relationship to spindle cell lipoma: clinicopathologic, immunohistochemical, and molecular analysis of six cases. Mod Pathol. 2010;23(5):729-36.

20. Åkerman M, Rydholm A. Aspiration cytology of lipomatoustumors. A 10-year experience at an orthopedic oncologycenter.DiagnCytopathol. 1987;3: 295-302.

21. N. de Saint Aubain Somerhausen. Lipomatous Tumors of Soft Tissues. InstitutJuleBordet.AvailablefromHttp://Www.Forpath.Org/0001/ Part1.Htm.24/08/2011. 